\title{
Reading the Ao-Naga Folksongs: Rewriting the Custom of Head Taking
}

\author{
Imchasenla
}

\section{$\underline{\text { Abstract }}$}

Besides the transformation brought to the Naga Hills by colonization and American missionaries, the subsequent colonial documentation/ representation of the community has been of academic and scholarly interest in the recent years. Naga Hills were turned into a field of study. The literatures of the colonizing cultures distorted the experience and realities of the Nagas and portrayed them as inferior. The literatures framed the mindset of the readers to see the Nagas as chaotic, irrational and primitive, savage and effeminate people while the colonizers as ordered, rational and masculine. This article aims to focus on the Naga custom of taking heads that served as the important foundation of the ancient Naga society. The Nagas in the colonial literatures by and large are famously known for their "headhunting" tradition. This custom has given them a widespread notoriety in the colonial documentary records and in the neighbouring valleys. In fact, no tribe has a more established reputation for "headhunting" than the Nagas and even today Nagas are strongly associated with the term "head-hunters" by other ethnic groups. At present,, this practice may sound "barbaric" and "savage" but this game of glory was a part and parcel of every Naga village and was a serious business where the social, economic, political and other significant aspects of the lives of Nagas were tightly interwoven to this custom. However, the invading, "cultured" colonial EuroAmericans promoted the image of "headhunting" as a 
cruel and barbarous practice. The standards of "evaluation" deployed by the ethnographers which was not really an anthropologist's array was not just. The ancient Nagas practised decapitation to serve a different purpose. Here, the intention is not to defend headhunting" as a practice, but to provide a socio-historical perspective of it from within, from the perspective of the Nagas.

Keywords: Nagas, Head-hunting, Nokinketer, Ao-Naga Folksongs, Rewriting

\section{Discussion:}

The adjectives such as "savages", "heathen", "barbarous", and "head-hunters" have been constantly used almost synonymously with the Nagas in colonial representations over decades. The usages of such derogatory concepts have resulted in misrepresentation and misinterpretation. Therefore, it is important to understand the community from the perspectives of an insider to contest the social constructions of the community by the outsiders. There is a need for a critical study of the Naga ethnography and for an attempt to revise and reassess the colonial literatures. A re-interpretation of the community and its culture by using different methodologies and with new perspectives is important to rise above the colonial anthropological and conventional interpretations. Such reinterpretation is crucially important to decipher the act of colonial representation and thereby, bring out a new meaning, a new identity. However, reconstituting or going home completely would be impossible since the Naga community has undergone tremendous changes and development over the years. It could only be reclaimed, revisited and realized in partial, fragmented ways. Helen 
Tiffin (1995) identifies this problem in relation to the African literatures as follows:

Processes of artistic and literary decolonization have involved a radical dis/mantling of European codes and post-colonial subversion and appropriation of the dominant European discourses. This has frequently been accompanied by the demand for an entirely new or wholly received 'reality', free from all colonial taint. Given the nature of the relationships between coloniser and colonised, with its pandemic brutalities and its cultural denigration, such a demand is desirable and inevitable. But as the contradictions inherent in a project such as Chinweizu, Jemie and Madubuike's the decolonization of the African Literature demonstrate....such precolonial cultural purity can never be fully recovered. (p. 95)

Tiffin talks about the infeasibility of creating and recreating national or regional formations that is wholly independent of the European historical implication in the colonial enterprise. At the impossibility of recovering pre-colonial cultural purity, however, she puts forward a vital and inevitable task to the colonized "others" i.e., to re-read and re-write the European historical and fictional records. She also emphasizes that the role/project of the post-colonial writing is to interrogate the discourses and strategies of the Europeans and to investigate the means by which Europe "imposed and maintained its codes in the colonial domination of so much of the rest of the world" (1995, p. 95). And such interrogation and investigation according to her is the "subversive manoeuvres" which is a characteristic of postcolonial texts. 
Tejaswini Niranjana (1995) states that the "post-colonial desire to re-translate is linked to the desire to re-write history." Rewriting according to her is:

...based on the act of reading, for translation in the postcolonial context involves what Benjamin would call "citation" and not an "absolute forgetting." Hence there is no simple rupture with the past but a radical rewriting of it. To read existing translations against the grain is also to read colonial historiography from a post-colonial perspective, and a critic alert to the ruses of colonial discourse can help uncover what Walter Benjamin calls the "second tradition," the history of resistance. (p. 172)

Thus, the potential of re-translation/re-writing as a subversive strategy of resistance against subjugation needs to be explored. Likewise, the Naga colonial narratives need to be liberated by taking recourse to re-translation and re-writing and reject the legitimized theory and practices framed by British imperialism. In the present day, Naga scholars create "new perspectives" and attempt to reclaim the ancient history and articulate and represent their identity drawing lessons from the rich oral tradition of the community. However, given the diversity of the Naga tribes, it would be impossible to do a research on the oral tradition of all the Naga tribes because of the vastness of the material. Therefore, to contest the colonial representation of the Nagas, the primary focus of this paper is limited only to the translation of the Ao-Naga folksongs. Through these Ao-Naga folksongs, an attempt is made to delve into the past lived experience and realities of the Ao-Naga community. This "new perspective" would give a new platform to the Nagas in general and Ao-Naga community in particular, to bring about change in the colonized consciousness of the readers which was framed and 
reinforced by the colonizers. For this study, the Ao-Naga folksongs would be taken as an indispensable tool to re-create and rewrite the lost past which in turn determines a present and a future.

\section{The Custom of Head Taking:}

Strange activities in other humans have the ability to catch the attention or fascinate people and the practice of "head-hunting" falls in this category. The term describes the practice of chopping off of the head of the fallen enemy and preserving the skulls for various reasons. "Headhunting" was practiced in the Naga Hills and other parts of Southeast Asia like the Ilongot of Philippines and Dayaks of Borneo. This practice served particular purposes for all these tribals. It was an aspect of their life, intrinsically linked to cosmology, agriculture, human fertility and religious power. It was also for defence and proof of manhood and spirituality. The inclination to take the head was seen as essential as many believed that the head represented the core of the personality. Therefore, to chop off the head was both an act of violence against and an insult to the fallen victim. It was also commonly believed that the soul lives in the head and taking an enemy's head would take its skills, strength, and power and therefore weakens the enemy's entire community. In many "headhunting" societies, skulls represented the most powerful magic in the world and vital transfusions of energy. Taking a head was a ritual passage to manhood, denoting the transition from childhood to adulthood. The proud owner of an enemy's head victoriously displayed it outstandingly and this increased his personal status. This practice has a long history as a supremely effective weapon and the more one could procure the heads, the more the status of the tribe as a whole increased because of the added bonus of helping to threaten existing or future enemies. And 
for that reason, those that have the highest trophies often had extremely fierce reputations (Linda Heaphy, 2014).

The Nagas in the colonial literatures by and large are famously known for their "headhunting" tradition. Earlier times like for many ancient tribes, for every Naga the custom of taking heads was an accepted customary existence and has extensively been "established as a custom in the process of history and had gained recognition as a sign of bravery" (Thong, 1997, p. 10). On the whole, the entire Naga life in the ancient period appears to revolve around the practice of taking heads and its glory. It was a custom practised to achieve social mobility in society as well as political and economic success (Longchar, 1999, p. 29). However, this custom has given them a widespread notoriety in the colonial documentary records and in the neighbouring valleys. In fact, no tribe has a more established reputation for "headhunting" than the Nagas. It is remarkable that Nagas are still strongly associated with the term "head-hunters" by other ethnic groups and whenever one utters "Nagas" the message invariably sent across is headhunting. The Nagas did practice taking heads but defining them as "head-hunters" is problematic because it carries an enormous potential for misinterpretation and misunderstanding. It sounds like a hobby or the only ultimate desire or objective of existence. It only serves as a justification for colonial intervention (civilizing the savages). In short, the usage of term Nagas as "head-hunters" is logically incorrect as it gives value judgment as substantiated by preceding discussions. Thus, the notion of "contest" arises here and the necessity to read the Naga struggles, from the perspective of the Nagas gains ground. 
The Nagas never addressed themselves as "headhunters."For instance, the only title that was awarded to an Ao-Naga warrior after procuring a mangko was Nokinketer. Nok meaning dao, in meaning power and keter meaning possessor that culturally meant a warrior using a dao with much power and valour. The cultural history of the Nagas in general defines the people as warrior tribesman and the Aos were no different. In the Ao-Naga society, the most prominent people were the warriors, and among the warriors, the Nokinketer were considered a cut above the rest. They were defined as good warriors, distinguished in war for success in many combats or for having killed many men at war. The Nokinketer with the power of the nok as the vanguard brought security, prestige, honour and prosperity to the people. The nok executed the power of might and strength. In the present context, this prestigious title has translated into a different usage. Influential and powerful learned Ao-Nagas in the society are called Nokinketers. Today the term Nok is metaphorically used as pen which is "mightier than a sword" as Edward Bulwer-Lytton has coined. Although the practice of taking heads is a thing of the past, contemporary Nagas are urged to use the past glorious power of nok to move forward to bring out many young Naga writers, intellectuals, and philosophers in the society. The power of nok is invoked to influence people and thereby play an important role in inspiring and guiding people.

Regarding the origin of beheading, there is a growing discrepancy of folktales among the Nagas and one such Ao-Naga folktale can be traced. According to the traditional Ao tale, they learnt this practice from the ants. In the beginning there was only one tree on the surface of the earth. This tree bore much fruit and all the birds settled on its branches to eat the fruits. One day a bird dropped one of the fruits on the ground and a lizard ate it up. When 
the bird searched for the fallen fruit, it was informed by the lizard that an ant had eaten the fruit. Since both the lizard and the ant denied eating the fruit, it was arranged that the case would be decided by taking an oath. After taking the oath, it was clear that the lizard was guilty. At this time all the ants chopped off the head of the lizard and took it out in a procession as a sign of victory, which was seen by human beings. It was in imitation of this incident that Ao-Nagas ritualized and practiced taking the heads of the enemies (Pongener, 2011, p. 46-47).The tale or myth about the beginning of this custom is enshrined in the short song:

Oh! In Chungliyimti, we Aos

With bare hands

Fought in battle

With bare hands alone

We the humans could not kill our enemy

Longsemba on his way to work saw

Black ants cut the lizard's head

Saw them yell their victor's cry

Imitating that on the day

When Pasa village was invaded

Hemsüla's head was cut and brought

From then on, we, the Aos, too started beheading.

The story and the song cited signify several things and work as clues to the Naga custom of headhunting apart from conflict with other tribes which were inevitable for survival in ancient times. The metaphors of bird, lizard and ant are significant. Ant is the smallest 
and most helpless of all and the lizard actually lies to birds. The ants were angered by the injustice meted out to them and hence, the right to anger. Secondly, though they are the smallest of beings, united they are a force. The song refers to fighting with "bare hands" and "bare hands alone" which could not defeat the enemy. It is then that Longsemba decides to go about the ants' way. He cuts the head of Hemsüla when the village was invaded. It is injustice and invasion that which is opposed and fought back in order to protect one's own community and people which is common to all cultures and civilizations in the world. Unlike big nations and kings, the small community of Nagas cannot afford to have a separate army to protect them, making a division of labour between them army and the civilians. Every member of the community is a warrior and protector. In such a society war and valour are cherished virtues and keeping war trophies as a proof of that is quite but natural. There is no community that does not have war literature, epics, poetry and narratives. Hence, calling a Naga warrior as an "aggressor" or describing headhunting as an unprovoked act and a "game" is uncalled for. Moreover, there is also a hint at the community's transformation from fighting with bare hands to acquiring weapons. This is how oral communities preserve their history through cultural memory.

The invading, "cultured" colonial Euro-Americans promoted the image of "headhunting" as a cruel and barbarous practice. However, the ancient Nagas practised decapitation to serve a different purpose. Traditionally, the Nagas differentiated between the soul (a celestial body) and the spirit (a supernatural being). They believed that the soul of a person resides in the nape of the neck and could only be set free by beheading and the spiritual being in the head would bring good luck and prosperity to the village. The 
practice of beheading was intimately connected with agrarian rites. The heads were considered as "manna" and essential ingredients in agricultural fertility rites. According to the beliefs of the Nagas, if a work in a new spot for cultivation was carried out without the sacrifice of a head, the spirit of the field would destroy the crops by causing drought or sending hailstorms, wild animals, birds and so forth. It was also believed that it would avert the displeasure of some evil spirits and please gods in times of an epidemic. Hence, head was regarded as the most precious gem among all, in fact an "intrinsic component of their culture as it was based on the concept of fertility and was thus the mainspring of their lives and activities" (Pongener, 2011, p. 47).

Among the Nagas, the practice of decapitation was also a space of contesting masculinity; a sign of bravery, prestige and honour. The desire for social recognition is a natural impulse in every human being and likewise a Naga would strive relentlessly to seek any opportunity to be socially recognized and wish for nothing more in life than to prove his worth, his strength and power as a warrior. A warrior who could procure a head earned the greatest honour of wearing elaborately designed traditional attires and ornaments which were envied by all and which could not be worn by everyone. Beheading was also closely associated with funerary and eschatological rites. It was believed by some Naga communities that the warriors whose heads they took would become their slaves in the next world. For this reason, several stone monuments were placed over the warriors' tomb to represent the number of heads they took while they were alive.

Every Naga village was an independent state and Nagas lived under the constant threat of raids and intertribal conflicts. And for that reason, the villages were usually located at the top of the hills 
and for security and defence. The practice of beheading was obligatory because those days "might was right" and Charles Darwin's theory of "Survival of the fittest" held well. It was their policy to slay the enemy's head before they were attacked. They executed this practice "as a call of duty to adjust themselves to their environment, and their very survival depended on it" (Thong, 1997, p. 10). An account of the intertribal raids or conflicts of the Nagas during the ancient period is briefly narrated in the short song below:

Oh! The enemies

Of the downstream of Tsüsu river

You may be united as the Fifi You may resemble the handsomeness of the warojakshi

But deep inside,

Bitter are your deeds.

Context: In the olden days, Longkhum villagers (an AoNaga village) and Sumi-Nagas were great enemies and were often engaged in raids. Tsüsu River is situated in the Longkhum village and the Sumi-Nagas resided in the downstream of the river. This song was sung by the Longkhum warriors to show their feelings of intense dislike and lack of respect for the Sumi-Nagas. They mocked at the nature of the Sumi-Nagas singing that they may be united as the Fifi bird and may look as handsome as the Warojakshi bird but not a soul should be lured by their outward beauty as their deeds are crooked and bitter inside.

In the words of Christoph von Fürer-Haimendorf (1938): 
Headhunting and frequent wars made intercourse between villages extremely difficult and cut off the people on the hills in the interior from all contact with the outside world, for traveling alone or even in small groups in the un-administered parts of the country is, for Nagas as for Europeans, a venture little short of suicide. "Cheap" heads of defenceless wanderers are only too welcome in every Naga village. (p. 201-202)

Taking an enemy's head in a raid was never a game of pleasure for Nagas. Fürer-Haimendorf's comment that "Cheap" heads of defenceless wanderers are only too welcome in every Naga village expresses colonial desire to visit and its anxiety and innocence of "unknown" territories and people. One should not also forget that the British Empire was interfering in the affairs of independent tribes in order to exploit them. In such situation it is not surprising if Nagas considered any one belonging to it as an invader. The song cited above clearly mentions the animosity between Naga communities and their struggle for survival.

Further, Fürer-Haimendorf's much sought-after "cheap" trophy was short-lived as in the latter part of his article he showed himself as an ambitious anthropologist devotedly procuring the skulls as "gems for museum display" that were left scattered in the KonyakNaga village of Pangsha when an expedition took place. The British Raj burnt the village of Pangsha and for Fürer-Haimendorf, it was agonizing to see the craftsmanship of the village ruined and reduced to ashes. Though the motives for procuring the trophies might be different for him and for the Nagas, but the pleasure of being a proud owner of the trophy is the same. In his article, he states:

Many heads hung from a tree... and I decided to take some of these heads back with me as anthropological 
specimens, is though we found a convenient basket in which to carry them none of the Nagas in our company volunteered to carry the heads. Thus I had, to the amusement of the Nagas and the surprise of the sepoys, to take the basket on my own shoulders........through all the fight I had carried the head trophies and I proudly brought them into camp when we re-joined the rest of the column some hours later. (1938, p. 209-210)

After Fürer-Haimendorf returned from the wild adventure, he shared the looted trophies with some of the administered villages of Konyak, and his "cheap" trophies only gained him the thrilling opportunity to take part in the after head hunting ceremonies that he claimed "no white man had ever watched" (1938, p. 212).

W.H. Furness (1902) held, “...now that the Indian Government has assumed control over the larger part of the hills south of the Dikku river, and has thrown a depressing damper on the distracting and highly diverting pastime of human head-hunting in raids on the hills" (p. 445-446). His judgment on the Nagas' game of glory as distracting and diverting pastime is an affront that reduced the rich cultural heritage of the Nagas to a mere activity of uselessness and of leisure time. The custom of taking head was a part and parcel of every Naga village and was a serious business where the social, economic, political and other significant aspects of the lives of Nagas were tightly interwoven to this custom. Often young men would take vows not to enter into any pleasurable activities until they had taken a head. Whenever a war was planned, the whole village would observe compulsory genna with fitting offerings and worship. Taking head was therefore not merely a diverting pastime game for ethical codes and fair means were strictly attached to the practice. Many different rules, techniques and groundwork were 
used to gain the trophy head as well as to defend themselves against any enemy attack. As losing in warfare would bring bad fortune and bad harvest to the village, strict ethics and code of conducts were maintained during the raid as well as in its preparation. Even W.C. Smith's comment on "headhunting" as a "mode of recreation" is contradictory because at the end he held that, "Whatever may have been the motives which prompted many Aos to take heads, they did not enter upon these things lightly. When a village would undertake an expedition, it was preceded by day of genna and fitting worship of the village gods" (1925, p. 73).

Certainly, the custom was never a mode of entertainment as the spirit of vengeance fuelled the practice of beheading for generations to come. R.G. Woodthrope (1882) who states that the Nagas were bloodthirsty, treacherous and revengeful expresses that "...it is an article of faith that blood once shed can never be expiated except by the death of the murderer or some of his near relatives and though years may pass away vengeance will assuredly be taken some day" (p. 26).Thus, the fear of vengeance was a strong deterrent to beheading and the act of vengeance greatly minimized acts of bloodshed in the Naga Hills and this verity is emphasized by J.P. Mills (2003):

On the other hand the number of persons killed on raids is very small; it is not often realized how small. Big scoops are made at times, but they are very much the exception and as a rule only occur in areas where for some reason there has long been peace, with a corresponding lack of vigilance. Usually a Naga war is a singularly innocuous affair, for both sides are on the alert. The Konyak villages of Tamlu and Namsang, with only a valley between them, were at war for sixteen years. The casualties on both sides totalled four. There were raids innumerable, but neither 
could catch the other napping, and an attack is never pressed home against an enemy who is ready. This is not an exceptional case. A village which lost on an average a head a year would consider itself subjected to a series of blows. (p. 209)

In the ancient tradition of the Aos, mangko unlawfully sought was condemned and disregarded, for it would draw hatred and unwanted animosity. It was only restricted to the enemy heads and whenever the villages were in raid. Only those mangkos that was lawfully gained were honoured and welcomed highly. A mangko fraudulently gained is seen in a responsive song sung by a mother and her deceased son who was tricked and killed by his friend. However, in the dream the anguished soul revealed the truth to his mother about the deceitful slayer. The folksong also reveals the value of a mangko that drove the warrior to even slay his fellow friend which was against the law of the practice:

I dream of you at night

Yet your presence at home is missing.

The changsen worn by you

Beautifies the doorway of my house.

My friend and I were at the enemies'letenjang

Yet I was not killed by the enemies' dao

My friend has no head

I plead not

To smear my flesh and face with arojang at the yimrong tree.

Context: Two good friends went to a raid with the aim to bring home scores of mangko but on the way to the enemy site, one of the friends tricked the other friend and 
killed him. The wicked friend was jealous of his friend who has procured mangko in a previous raid. The first paragraph was sung by the mother seeing at her son's ill fate. In her dream she could see only a half part of the son's body in the doorway wearing changsen. She was heartbroken as the son was no more alive even though she sees him in her dream. The second paragraph was the reply of the son to his mother. He narrates the tragic episode that when they reached the enemy's roadside, he was tricked by his friend and was murdered. In the song, he scorns the unfaithful friend that he is not a brave warrior and has not procured any mangko. At the end, he is seen asking the enemies not to perform any rituals upon his dead body when they find him. He also asked the enemies not to rejoice and strew arojang on his face and smear his face with white flour before his head was hung in the enemies' yimrong as he was not splayed by them but by his own native fellow friend.

It was also considered a taboo to slay the head of a person belonging to the same clan though living in different villages and also restricted to slaying an insane or infirm person. However, in some contexts, sex or age had no consideration. In fact, warriors were highly praised and honored if they could bring the mangko of a woman and a child. The reason behind is that children and women were not allowed beyond the vicinity of the village and were wellprotected. Even the women in the fields were well guarded by the warriors. Therefore, a warrior's prestige gets higher because such mangko could only be procured by an extraordinary act of courage. However, some Naga tribes do not slay children and women. According to the Ao traditional reports, the first mangko procured 
was that of a woman which acquired for the Ao-Nagas the reputation of being a head hunter (Longchar, 1999, p. 29).The mangko of a female with long hair was deemed as more valuable and highly priced especially because of the difficulty of getting it. Female hairs were used as a valuable source of decorating spears, daos (Naga machete) and headgears for warriors.

Among some Naga tribes, during the raid, if a helpless person called out "father" to the raider who is ready to slay him, that person's life was to be spared and was to be taken captive. For the Aos, if the captor wished to make peace, the prisoner's life was spared in order that he would be used as a negotiator between enemy villages. He would be made to put up a stone under the head-tree/ skull tree and to take an oath that until the stone rotted he would not make war on his captors anymore. After his release, he would become a lampur, meaning "the go-between between villages." The lampur who enjoys a sacrosanct existence could go with perfect safety to a village with which his own village was at war and a lampur, even if he is from a hostile village must on no account be killed. It is through them that peace negotiations were carried between villages.

Here is a song sung by a young man whose life was spared from the hands of the enemies:

The fearless Longin warriors attacked Azümonglo

Longin! The Great warriors

Even held Phirrülu as hostages

Mongzü do not match up your vigor

But strong and swift as Orijang. 
Context: The Longin warriors captured the young man with the intention to kill him. In the intense hour of danger, the young man in order to save his life started singing of their bravery and triumphs. He sings that the Longin warriors have not only defeated the Azümonglo warriors but also captured the Phirrïlu villagers as hostages. So powerful and fearless are the Longin warriors that mongzü bird cannot match them as their swiftness matches the swiftness and the strength of the orijang bird. Because of this praiseworthy song, his life was spared and escaped death.

Occasionally when two enemy villages reach a decision to wage a war against each other, they would agree to meet at a certain spot. Such an arrangement according to the Aos was called tungpangrarr (Chungli) or tungpangtep (Mongsen), meaning "to fight a battle." When a village reached a decision to wage war against an enemy village, a messenger was sent to it with the message of an impending attack and decided on the number of days after which the war would be carried out. Also, decapitation was practiced when circumstances of wicked raids and feuds raged out between villages. It was also the custom for the stronger villages to demand subservience from weaker villages. When this was refused, war was declared. There were also raids where heads were taken due to disputes over boundaries and land. Aluayen (Chungli) or aluyen (Mongsen) was the most common form of attack where a party of raiders would attack especially women and children working in the rice-fields and the raiders could make a good escape before help could arrive. The next common attack was tamamen (Chungli) or tumentang (Mongsen), an ambush that would be laid by a path along which people were most likely to pass. The raiders would hide behind a thin screen of jungle purposely left uncut, holding branches in front of their faces and with their spears every ready to attack. 
Another favourite form of attack was by lurking by the springs and killing the women and children when they came to fetch water. And sometimes, the raiders cut the aqueduct that brought water from the stream to the village path. When one or two men went out looking for the break, they would walk straight into the ambush. It was told that tigers knew this trick and would dislodge a section of the bamboo channel and then seized those who go to mend it. For this reason, even today, no one goes alone to repair an aqueduct. And because of such surprise attacks, women and children went in large parties to the jungle to collect firewood and to the springs which were well protected by the village men.

After the war ended, the expiatory ritual process involved catharsis and cleansing of the community of the impurities of bloodshed. The raiding party did not go home because it was genna (taboo) as war was considered contaminating and unclean. The warriors were to be ritually cleansed and also the entire community was to be cleansed of the impurities of the war. Therefore, purification ceremonies and necessary sacrifices were made before resuming a normal life. The warriors observed genna for some designated days at the morung. During the genna period, they slept and ate food prepared on temporary hearths and ritually washed their weapons and bodies. Since the warrior's hands and weapons were considered defiled, they used special stiff leaves called war-spoon leaves to feed themselves and the end of the genna, all the utensils were destroyed.

According to the tradition of the Aos, the mangko was hung by cane strings to the end of a long bamboo which was made to lean against the branches of the head-tree/skull-tree. The Tir (leader) under the tree plucked a chicken alive with a declaration that the mangko was taken only as a revenge for the offence committed by 
the enemy village. Prayers were offered for more mangko, human and animal fertility. Finally, the chicken's throat was cut with a bamboo knife and omens were taken from its entrails. It was firmly believed that if the village failed to observe and fulfil the ceremonial obligations, it would result in untoward misfortune for some individual or for the village as a whole. When a foe was killed, it was also expected to treat the dead body with reverence, because the desecration or ill treatment of the dead body was considered genna and would also bring retribution upon oneself and the village (Thong, 1997, p. 378). On the sixth day after the mangko was hung up, the warrior took down his piece and cleaned it and if married, hung it up on the outside of the front wall of his house but if unmarried, he hung his trophy up in the morung. In some Ao villages, dogs' skulls were hung above each human skull. The reason is that if the dead man's relations call him, the dog would bark and the departed soul could not hear them and tell them who had killed him.

The rituals performed on the mangko and the magical works that happened afterwards is transcendental and inexplicable. An instance that guaranteed good crops and fertility can be seen in the experience of Fürer-Haimendorf when he was on fieldwork in the Konyak village of Wakching, who states that:

All the people of Wakching were convinced that this year, in which the heads have been brought in, would have a particularly good harvest, and when I left Wakching in June the promise of the crops seemed really better than they had been for many years. It is obvious that the bringing in of the head does not only provide an opportunity for feasting, a pleasant interruption in the monotonous life of a Naga village, but it exerts also a 
stimulating influence on the economics of the people. (1925, p. 214)

For a Naga what eggs him on to fight and succeed in the war was the most deep-lying drive because a man's social position depended upon his success in war and also ensured a glorious memory after his death. Hunger for respect, fame and honour stirred the heart of every Naga as well as that of the noblest soldier who ever marched under the British colours. To the Naga, there was nothing more glorious and brave than procuring a head trophy. A warrior who had taken a head was ceremonially honoured and respected. It was every warrior's desire to own a head as his praises would be sung and was held in the highest esteem. The strongest and the most courageous men were lauded by the villagers especially the womenfolk. Therefore, there was always a contest among the young warriors to be the best. A warrior with head not only gets the honorary title but the prospects of scoring a beautiful bride increase proportionately. Men were ridiculed and were called boys or woman or even cows until they had contributed to the village skull-tree. Even the villages that had taken only a few skulls were looked down upon. The song below compares brave warriors with coward folks who choose to remain at home. This song also emphasizes the importance of every warrior to bring mangko to the village:

Anyone not going to the battle

Is like a far-off cotton flower.

But anoknaro of MoyaTsüen awaits

In the pathway

Those who press onward to the battle. 
Context: This is a song that mocks the cowards who avoided being a part of the gallant game. The brave warriors sing that those who march to the battle will be rewarded by the anoknaro or mango of MoyaTsüen and continue to scorn at the coward folks that their only rewards will be mere kumbanaro (Kumba meaning cotton, naro meaning flower). Referring to a man as a kumba naro is an insult to a man's masculinity.

Another song shows the brave warriors teasing and mocking those men who were not brave enough to join a pitched battle:

Those who do not go to the battle

Do not touch the dao's decorations

Lest the streets feel shy

Oh! Those who do not cut the enemy's head in battle

Bind your hair in the likeness of a woman's kolang

And burn ngüpsen

Far in the village of Tsüen

As a warrior's decoration

The anoknaro

Waits.

Context: The brave ones sing that the cowards are not entitled to touch a warrior dao's decoration and the mankgo. They ridicule that because of their cowardice, the villagers mock and laugh at them in the village street. They decry those without any mangko to merely bind their hairs like a woman and bear the great humiliation. Bravery and pride raged in the breasts of these warriors claiming that they are not scared of devils that were usually chased away by ngüpsen. For them, a warrior's only decoration is the anoknaro or mangko of the Tsüen (Sumi-Naga). 
Special occasions of festivity and ceremonies were also the golden opportunity and platform for the warriors to flaunt their prized possession trophies with pride and vigour. During these periods, the Nokinketer were bestowed with a degree of social prestige and popularity. Women and children also attended these festivals with enthusiastic enjoyment wearing beautiful attires and ornaments and joined the celebrations honouring the warriors through songs of praises. In their song of praises, the heads were held as the most significant and the greatest achievement of all. Even sacrifices of scores of mithuns were not comparable to their achievements. The more heads a warrior could gather more songs of honour and praises were showered upon them. In the participation of the Naga women and children after a successful raid, Smiths comments as:

It seems rather strange that the women should do all in their power to encourage such practices, for it was they and the children who suffered the most, since they were unarmed and not so fleet-footed as the men. Thus, it was, but still they sang the praises of the successful warrior, while they scornfully laughed at the young men who attended the feasts without the adornments which distinguished the successful warrior. (1925, p. 72)

However, as evident from the preceding points discussed, decapitation practice was closely associated with many factors of establishing wellbeing and propriety. The practice was not the least a rational act and not just a game for pleasure. It was something more than a barbaric act and it is not one of the worst horrors of the world as it was sometimes thought to be: 
The practice of head-hunting is found all over the world and has attracted great attention. So-called civilized countries, which can destroy whole populations with a single atom bomb, can hardly afford to look down on a method of ritual warfare which, at most, involved the loss of a few hundreds of lives every year. (Elwin, 1969, p. 11)

In Bombay, more than half of the children die before they are one year old. In 1921, the figures were 666 per thousands. There are forces against which no popular outcry is raised, far more destructive of human life than head-hunting. (Mills, 2003, p. 210)

The glory of procuring head inculcated many positive values such as discipline, perseverance, vigilance at all times, abstinence from objectionable foods, and the practice of chastity. The essence of this practice had a socio-cultural, religious and political significance. It inspired wonderful dances and artistic productions such as elaborate traditional textiles to be worn only by a Nokinketer. In the Naga societies, variety of artefacts symbolizes clan identification, social status, wealth and valorous deeds. Such artifacts include weapons, carved objects, weavings, ornaments as head dresses and jewellery and sometimes the head themselves. Small replica of head was carved out to be worn and also vigorous human figures were carved and attached to the baskets. And the graves of the Nokinketer were the most splendid of all where human skulls were placed on the corpse platform as an insignia of valour. Thus, from the preceding discussions it can be noted that the many facets of the Naga practice of taking the head were often overlooked. 
To sum up, the colonial construction of head-hunting as a barbaric practice amounts to misread the values and customs of the Naga communities and it is a reading full of colonial and racial prejudice. It is done in a time when the European nations have colonized the rest of the globe with their treacherous schemes, horrible wars and everyday killings. It is the expansion of the Empire that gives an opportunity to study others and the power of colonialism that provides legitimacy to their narratives. In turn, these narratives provide legitimacy to colonialism and the white man's burden.

As far as war and killings are concerned human race is not free of wars and violence even today. The ways, strategies, ethics and values differ from place to place and people to people. No one can be proud of it. But power provides legitimacy to certain form of violence and it delegitimizes certain other. As a small community the Nagas had to go to war for their self-protection, economic prosperity and survival in which the bravery of its members becomes paramount and celebrated. Modern societies are not free from such forms of rewarding and celebrations. Hence, an ethnographer has to understand a society from its own terms and to historicize the ways of life, beliefs, customs and social practices of a community while describing it. Yes. Nagas fought their wars! So are other communities. Yes. There was violence and celebration of bravery! So was in other communities. But let us not gloss over the fact that like other communities they too had their values, ethics, beliefs, cosmological explanations and rituals related wars. Here, our intention is not to defend head-hunting as a practice, but to provide a socio-historical perspective of it from within. It was just a "moment" in the history of the Naga people. For this reason the 
standards of "evaluation" deployed by ethnographers which was not really an anthropologist's array was not just.

\section{Notes:}

1. Mangko is the enemy head in Ao dialect. It was the prized owned trophy.

2. Nok which also means dao is a hatchet with a long blade carved in wooden handle. It is also known as a Naga weapon or one of the most important equipment as it serves many purposes, especially in the past, for their survival. Nok is seen as lifegiving and life-taking because it saved many lives and killed many lives too in the past. There are different types of dao used for different purposes viz., head hunting, animal hunting, working and ceremonial daos. During the ancient period, nobody could predict as to when and from which direction the enemies would come. Therefore, men of a particular age group were always kept ready with the war equipment to fight with their enemies. The adult male members of the family were ever alert with weapons, such as dao, spear, war shield (bamboo shield) and spikes (aso), or bows and arrows. When a mangko was brought to the village severed by a dao, was sanctified again (Ao, 1999, p. 60-61).

3. A name of a river in the Longhkum village of the Aos.

4. Fifi is the name of a bird in Ao-Naga Mongsen dialect. Fifi bird tends to stay in big group.

5. Warojakshi is the name of a bird in Ao-Naga Mongsen dialect.

6. The concept genna is used in two ways. It may mean practically a holiday, i.e., a man will say my village is doing genna today, by which he means that, owing either to the occurrence of a 
village festival or some such unusual occurrence as an earthquake, an eclipse, or burning of a village within sight of his own, his village people are observing a holiday; genna means anything forbidden. Verrier Elwin, The Nagas in the $19^{\text {th }}$ century (London, Oxford Univ. Press, 1970), 514.

7. Changsen is an Ao-Naga traditional leg gloves worn by males on special occasion of festivity. It is worn between the ankles and knees.

8. A road or a surrounding nearby a village or a region.

9. In the ancient times, the mangko was brought to the yimrong (the place where the heads were hung on a tree for public display)and before hanging it on the tree, they performed some rituals. The mangko was first strewed by the arojang (pig weed) and was smeared with white flour.

10. The Konyak-Nagas also set up witness stones when making peace. If either party intends to break the oath or the peace, breach of covenant must be explained and justified to the stone first.

11. Mongzü is a large and lightish-colored bird, as large as an eagle or large hawk with piercing cries. The Ao believes that this bird has the spirit of some dead person. It is believed that this mongzü is apt to appear three/ four days after a man's death and such a bird is called the tanela (soul) of the deceased. The Aos also have superstitions that if this bird appears at other times, it is supposed to be an omen that some deceased relative in the form of a bird is calling and so someone will probably die soon. 
12. Orijang is a large hawk or kite that is rather swift and bad for carrying off domestic fowls. It is also known as the bird pursuer and killer.

13. Aos has several dialects of which Chungli, Mongsen and Changki are the prominent ones. Chungli dialect is accepted as the standard dialect of Ao community. All the printed works of the Ao language are in this dialect.

14. Morung was an ancient Naga traditional learning institution or the dormitory for the young unmarried men. It was also a village guard house, a barrack where men would sleep at night and supposed to be in readiness to repel any night attack on the village. In Ao language, Morung is known as Ariju.

15. Anok meaning dao, naro meaning flower which means mangko.

16. Moya meaning Sumi-Nagaand Tsüen meaningLotha-Naga tribes. In the ancient period, these tribes were regarded as enemies by the Ao-Nagas.

17. A hairstyle in which hair is put into a tight roll at the back of the head.

18. An incense used by women to frighten the devil.

19. A species of Indian bison domesticated in the jungle, mainly used for the "feast of merit" and was also used as currency.

\section{References:}

Ashcroft, Bill, Griffiths, Gareth, \& Tiffin, Helen. (1989). The Empire Writes Back: Theory and Practice in Post-Colonial Literatures. London: Routledge. 
Ao, A. Lanu. (1999). Naga Cultural Attires and Musical Instruments. New Delhi: Concept Publishing Company.

Bennet, Andy. (2005). Culture and Everyday Life. London, Thousand Oaks, New Delhi: Sage Publications.

Clark, Mary Mead. (1907). A Corner in India. Philadelphia: American Baptist Publication Society.

Elwin,Verrier. (1970). The Nagas in the $19^{\text {th }}$ century. London, Oxford University Press.

Furness, W.H. (1902). The Ethnography of the Nagas of Eastern Assam, The Journal of the Anthropological Institute of Great Britain and Ireland. 32, 445-446.

Fürer-Haimendorf, Christoph von. (1938). Through the Unexplored Mountains of the Assam- Burma Border, The Geographical Journal 19 (3), 212.

Heaphy, Linda. (2016). The Practice of Headhunting. Kashgar. Retrieved from http://www.kashgar.com.au/articles/headhunting Imchen, Panger. (1993). Ancient Ao Naga Religion and Culture. New Delhi: Har Anand Publication.

Longchar, Imtilemla. (1992). Portrayal of Women in Drama. Jorhat: Barkataki \& Company (P) Ltd.

Niranjana, Tejaswini. (1995). Siting Translation: History, Post Structuralism and the Colonial Context, Hyderabad: Orient Longman Limited.

Pongener, Mar. (2011). Morung Speaks. Assam: CTC and TDCC. 
Smith, W. C. (1925). The Ao Naga Tribe of Assam: A Study in Ethnology and Sociology. London: MacMillan and Co Ltd.

Thong, Joseph S.(1997). Head-Hunters Culture. Kohima: Nei-u Printing Press.

Tiffin, Helen. (1995). Post-colonial Literatures and Counterdiscourse. In Bill Ashcroft, Gareth Griffiths and Helen Tiffin(Eds.), The Post-Colonial Studies Reader (p. 95). London: Routledge.

Woodthrope, R.G. (1882). Notes on the wild tribes inhabiting the socalled Naga Hills, on our North-East frontier of India (Part I). The Journal of the Anthropological Institute of Great Britain and Ireland, 11 (26). 